\title{
From the RDP to the NDP: A critical appraisal of the developmental state, land reform, and rural development in South Africa
}

\author{
Abdulrazak Karriem \& Mark Hoskins
}

\begin{abstract}
After decades of neoliberal rule in which market forces held pre-eminence in shaping development, there has in recent years been a resurgence of an activist developmental state in promoting economic development and tackling poverty and inequality. This article explores the resurgence of developmental state thinking in South Africa. Specifically, the article critically appraises the functioning of the post-apartheid state as it relates to land reform and rural development and argues that a weak bureaucracy and a policy fixation on the neoliberal willing buyer, willing seller policy framework militates against the promotion of a thorough-going land reform and rural development programme to promote rural livelihoods. We argue that South Africa needs a developmental state that will construct a skilled and competent bureaucracy, a centralised planning agency with the power to coordinate and ensure that government departments work together, and that will actively intervene in the economy to meet developmental objectives.
\end{abstract}

\section{Introduction}

Since the birth of democracy in 1994, the post-apartheid state has struggled to substantially address the deep socio-economic legacies of the apartheid era. While progress has been made in addressing the apartheid legacy, poverty, inequality, and unemployment remain stubbornly high. In light of the extreme socio-economic cleavages experienced by the majority Black population, the ANC-led government saw an interventionist or a developmental state as the vehicle through which to transform the economy, create jobs, and provide long denied needs, including land and housing.

The South African debate on the character that the post-apartheid state should assume has traversed the social democratic Reconstruction and Development Plan (RDP) which propogated an activist role for the state to intervene in the economy, engender economic growth, and redistribute wealth. By contrast, the Growth, Employment, and Redistribution (GEAR) programme, implemented in 1996, gave prominence to market forces in setting the development agenda. In 2011, the government-appointed National Planning Commission (NPC) released the National Development Plan (NDP), which commits the nation to 'building a capable state' that will eradicate poverty and create 11 million, including 1 million rural jobs, by 2030 (NPC 2011). In this paper, we will critically assess the RDP and GEAR, and appraise whether the NDP's 
ambitious targets are feasible in light of the performance of the South African state since 1994 with specific focus on land reform and rural development. For it is in this context that poverty and land inequality remain extremely high.

Our central argument is that the government's market-oriented 'willing buyer, willing seller' land policy and a weak bureaucracy constitute major barriers to meeting the target of redistributing $30 \%$ of white agricultural land to black farmers to create jobs and eradicate poverty. Moreover, we assert that the NDP, in leaving the market-oriented focus of land and agricultural policy intact, is unlikely to radically transform the agrarian economy or create a million new rural jobs. Finally, we argue that the NDP's objectives will only be achieved through a transformative developmental state with a skilled and competent bureaucracy, a strong centralised planning agency that has the power to coordinate and ensure that government departments work together and implement policies according to plan, and a state that will actively intervene and expropriate land to meet government objectives.

We commence the paper by reviewing some of the key debates on the developmental state highlighting how developmental state thinking has evolved from the twentieth to the twentyfirst century; investigate how scholars have drawn on some of the core requirements for constructing a developmental state in South Africa; critically evaluate state action in the postapartheid period through the RDP and GEAR programmes; and then outline what the NDP proposes to achieve. We then briefly outline South Africa's socio-economic profile in the post1994 period. Subsequently, we critically appraise land policy and implementation and argue that the dysfunctional nature of the state bureaucracy and government adherence to a marketoriented policy militates against the promotion of a thorough-going land and rural development programme that can address the apartheid legacies of widespread unemployment, poverty, and land and income inequality. In this section, we also interrogate the functioning of the state bureaucracy and the role that a centralised planning agency can exercise in building a strong, transformative developmental state.

\section{Theoretical considerations on the developmental state}

The term 'developmental state' generally evokes the East Asian experience of rapid transformations from poverty and economic 'backwardness' to modernised, technologically advanced industrial economies. Johnson, in his seminal analysis of Japan's post-war economic modernisation, provided the original framework of the developmental state as one that 'sets specific development goals and then single-mindedly mobilises society to achieve industrial modernisation' (Gumede $2009,4)$. In this formulation, the state actively intervenes to ensure that developmental objectives are achieved instead of letting market forces determine the allocation of resources $(2009,4)$. In their investigation of industrialisation processes in South Korea and Taiwan, respectively, Amsden (1989) and Wade (1990) also highlight the discipline and guidance exercised by the developmental state over private firms. In contrast to many middle-income countries, Amsden (1989) notes that the Korean developmental state subsidised targeted private sector industries, but enforced strict adherence to national development goals as a condition for accessing subsidies. In this regard, Ziya Onis argues that the capacity of these developmental states to 
discipline and direct private business is explained by their 'unusual degree of bureaucratic autonomy' $(1991,114)$.

State 'autonomy' is widely acknowledged as one of the central features of successful developmental states. In his path-breaking study, Embedded Autonomy: States and Industrial Transformation, Evans (1995) posits that a developmental state should be autonomous to ensure that it is not captured by powerful elites who seek to advance their narrow rent-seeking interests. However, he further argues that the state must also be embedded in civil society networks that are committed to core national development goals. Evans distinguishes the developmental state from a patrimonial or predatory state (e.g. the then Zaire under the Mobutu administration) which is captured by elite interests. To prevent elite capture, the state's decision-making bodies have to be insulated from all political and economic pressure groups, which Johnson (1986, 560) refers to as an 'open division of labour between reigning and ruling'. In effect, this entails granting the bureaucracy sufficient scope to take initiative and operate effectively (Johnson 1982, 315). Specifically, the developmental state maintains its autonomy from predatory elites through the establishment of effective Weberian-type meritocratic bureaucracies that are committed to advancing national development goals.

The success of the Korean developmental state and the implementation of its vision were dependent on the 'brightness of the state bureaucrats', who were subjected to a rigorous system of recruitment (Amsden 1989, 52). Effective, well-trained and skilled bureaucrats add to the autonomy of the developmental state because they are not beholden to the interests of predatory groups. They are able to negotiate with private groups by employing both formal and informal channels and, in doing so, they do not compromise governmental goals.

In addition to a solid bureaucracy, Evans and Rueschermeyer argue that there must be a strong degree of 'coherence and co-ordination' within and between different state departments or agencies, so that different parts of the state are more responsive to the leadership and coordinating action of the state $(1985,55)$. Indeed, most successful development states had a strong central coordinating or planning agency with the power to intervene in departments and ensure that the state's long-term development plan was followed. How South Africa's NPC fares in comparison to East Asian planning agencies will be a good yardstick through which to assess the government's commitment to the establishment of a 'capable developmental state'.

\section{A re-appraisal of the developmental state}

While much of the literature draws on classic notions of the developmental state as exemplified by the East Asian experience of the mid-twentieth century, there are growing calls to reappraise the role of the state in light of the socio-political and economic transformations of the late twentieth and early twenty-first centuries (Evans 2010, 2014; Williams 2014). This reappraisal of the state takes places in a context in which development theory itself has been enriched by new perspectives that analyse economic development since the late twentieth century. For Evans $(2010,2014)$, there are three key perspectives that shape contemporary development theory and that have implications for how we analyse the role of the state. First, new growth theory or endogenous growth theory holds that economic growth is propelled more by the production of 
ideas and human capital than by the accumulation of capital. Second, the 'institutional turn' in development theory emphasises the importance of 'shared normative expectations or "rules of the game"' in fostering economic action. The coming together of "social institutions that fosters ... investment and innovation "trumps" both resource endowments and the accumulation of capital in explaining national differences in the growth of outcomes' (Evans 2010, 42). Amartya Sen's capability approach, which constitutes the third cog in renewing development theory, posits that economic growth is not an end in itself, but rather a means to improving human well-being. Public deliberation is a central avenue through which to organise 'capabilities' and 'puts political institutions and civil society organisations at the centre of developmental goal setting' (Evans 2014, 224).

For Sen, the expansion of capabilities (like education and health, for example) is both the main objective of development and the primary avenue through which development is realised. Here there is strong overlap between new growth theory's focus on knowledge and skills as important ingredients of economic growth, thus reinforcing the notion that the enhancement of capabilities is a key driver of growth. Moreover, proponents of the institutional approach have given great attention to the 'causes and consequences' of the types of collective goal setting that underpins the capability approach. These three variants of development theory place great importance on institutions to frame collective goals, deliver collective goods (like education and childcare, for example), and uphold general rules and norms, thus highlighting the central role that effective state institutions can exercise in ensuring development success (Evans 2014, 224).

The global economy has undergone massive transformations in recent decades, which poses new challenges and provides new opportunities for re-focusing state functions in the twenty-first century. In the twentieth century economic growth was 'machine-driven' or centred on manufacturing as countries such as South Korea, Taiwan, and Brazil transitioned from largely agrarian to industrial and manufacturing-based economies. By the late twentieth century, however, manufacturing has experienced a steady decline with manufacturing-based employment in the USA, the UK, Canada, and Australia dropping from a high of almost $48 \%$ in 1950 to an average of $17 \%$ in 1998. The Global South has also been impacted by the winds of deindustrialisation, with China and India also experiencing losses in manufacturing jobs (Williams 2014, 9). Moreover, Evans notes that globally 22 million manufacturing jobs were lost between 1995 and 2002, and that even in the world's manufacturing power house, China, technologically advanced manufacturing production in the southeast region by joint-ventures and foreign-owned companies has increased economic output, but with declining employment levels (2014, 227-228). Whereas the twentieth century was machine-driven, twenty-first century growth is increasingly 'bit-driven' and adding value to products is increasingly generated through new ways of organising bits of information and formulas and less through the 'physical manipulation of materials to make tangible goods' (Evans 2014, 222).

While manufacturing (and agriculture) remains significant in many developing economies, it has ceased being the principal driver of economic growth and employment. The rapid growth of the services and information and communication technology-influenced sectors poses new challenges that push aspirant developmental states to give greater attention to people and their 
skills rather than machines. The bit-driven character of twenty-first century growth therefore calls for a more expansive role for the state in providing capability-enhancing services compared to what was required by twentieth-century manufacturing-driven growth (Evans 2010; 2014; Williams 2014).

While South Africa and other countries can certainly learn from the East Asian experience, this cannot be based on an uncritical embrace of the East Asian model. Rather, the construction of a South African developmental state must be rooted in an on-going reflexive and creative process of 'learning by doing' (Evans 2010). Moreover, the export-oriented East Asian model evolved in a particular historical, political, and geo-political context of the mid-twentieth century in which there was greater acceptance of strong, undemocratic states. By contrast, the late twentieth and early twenty-first century states, including those in South Korea and Taiwan, were characterised by civil society mobilisations for democratic rule and a neoliberal economic conjuncture in which market forces shape development.

The East Asian model is usually analysed from the perspective of industrial policy, and how this policy transformed economically 'backward' countries into modern industrial and export-led manufacturing centres. While this analysis is certainly true, there is another less studied component of this success: land and agrarian reform. The success of South Korea and Taiwan is also due to the implementation of agrarian reforms that helped to restructure the agrarian sector by breaking up unequal landholding structures and redistributing land to peasants and the landless, who then become the drivers of capitalist accumulation in agriculture (Byres 1996). These state-driven agrarian reforms thus played a decisive role in tackling rural poverty and landlessness, helped dynamise the agricultural sector, and created a large rural market for manufactured goods. In these countries, agrarian reform was an integral component of a larger NDP (Evans 2010; Moyo 2010). Agrarian reforms include both land and agricultural reform, and both must be implemented to transform the rural economy and society. The next section investigates how scholars, political parties, and development practioners have drawn on developmental state theory to assess how it could inform the construction of a developmental state in South Africa.

\section{South African interpretations of the developmental state: from the RDP to GEAR to the NDP}

William Gumede states that for the ruling ANC government, the building of a democratic developmental state is 'simply not an option'; it constitutes a 'moral imperative' because the nation's continued stability is dependent on it $(2009,13)$. Drawing on the East Asian experience, Gumede (2009) along with Edigheji (2010), Turok (2008), and Pillay (2007) raise some core aspects for a successful developmental state: political will, a long-term vision and determination on the part of the country's political elite to drive a development project, a meritocratic bureaucracy that places attainment of developmental goals and service to the country above personal and political interest, and the establishment of a central planning unit that drives economic and social transformation.

South Africa's debate around the character of the developmental state has traversed the RDP of the early 1990s, the GEAR programme in the mid-1990s to the notion of 'Building a Capable State' 
as enshrined in the NDP of 2011. The ANC, via the RDP, saw the state as exercising a 'leading and enabling role' in the economic and social transformation of the apartheid era economy and society. Moreover, the RDP foresaw the necessity for a central planning agency to redress the 'excessive departmentalism [that was] leading to uncoordinated, sometimes, contradictory decisionmaking by various state agencies' (Makgetla 2008, 151). To this end, the RDP office, located in the presidency, was established in 1994 to exercise a coordinating role, but it was understaffed, which limited its ability to coordinate and lead government programmes. In 1996, the RDP office was closed, leaving the state without a strategic oversight agency. The closure of the social democratic-oriented RDP office signalled the shift to the market-oriented GEAR macroeconomic programme, with government coordination now overseen by the Ministry of Finance (specifically the Treasury), which was more concerned with maintaining fiscal discipline than promoting broader developmental goals (Cosatu 2005; Makgetla 2008).

The move from the RDP to the GEAR also marked a shift from an interventionist and redistributive state strategy to a broadly neoliberal framework. In contrast to the RDP, which promoted 'growth through redistribution', the market-oriented GEAR was ensconced within a 'redistribution through growth' perspective, leading Pillay $(2007,201)$ to argue that the adoption of GEAR left the country in a:

schizophrenic limbo between two conceptions of the state: on the one hand a neoliberal conception, where a procedurally democratic state is reduced to a facilitator of market-driven 'development', and obsessed with the fiscal deficit, and on the other, a substantively democratic developmental state that intervenes decisively to eliminate the social deficit.

In line with its conservative orthodoxy, the state played a 'facilitative' role as GEAR's marketoriented policies induced competition in the industrial and agricultural sectors through deregulation and liberalisation of trade, and committed the country to a position of fiscal discipline. GEAR reigned supreme until President Mbeki was deposed at the 2007 ANC National Conference in Polokwane and replaced by Jacob Zuma. At Polokwane, the South African Communist Party, COSATU, and left wing and nationalist elements within the ANC mobilised for the transformation of the South African state's laissez faire role into an active and developmental one. As the 2007 Conference resolutions noted, 'there was a broad consensus to build a developmental state with specific South African characteristics' and that such a state will have the 'capacity to intervene in the economy' to 'address the challenges of unemployment, poverty, and underdevelopment' (ANC 2008, 17). Moreover, the Resolution on Rural Development noted that the:

willing buyer, willing seller approach to land acquisition has constrained the pace and efficacy of land reform. It is clear ... that the market is unable to effectively alter the patterns of land ownership in favour of an equitable ... distribution of land. (ANC 2008, 27)

Polokwane was instrumental in the establishment of the NPC which was tasked with drafting a long-term NDP. The NPC set a number of goals that the NDP had to achieve by 2030: poverty must be eradicated; inequality reduced; employment must increase from 13 million in 2010 to 24 million 
though improved economic policy coordination and implementation; per capita income should be boosted from R50 000 in 2010 to R120 000; and a million jobs must be created in the agricultural sector, with land reform playing an important role (NPC 2011). The principal driver of these ambitious targets was the 'capable developmentalstate'.

The New Growth Path (NGP) released in 2010 by the Economic Development Department (EDD), headed by Minister Ebrahim Patel, and the Industrial Policy Action Plan introduced by Minister Rob Davies of the Department of Trade and Industry, were, like the NDP, similarly committed to addressing poverty, inequality, and South Africa's unemployment challenge. The neo-Keynesian NGP targets 'more labour-absorbing activities across the main economic sectors - the agricultural and mining value chains, manufacturing and services' (EDD 2010, 9). To promote rural development, the NGP set itself the goal of improving the livelihoods of 300,000 smallholder households, and generating 145,000 jobs in agro-processing by 2020 (EDD 2010, 11). While there is a strong overlap between the goals of the NDP and the NGP, the latter policy has a stronger commitment to addressing inequality by "expanding livelihood opportunities at the lower end of society and containing enrichment at the upper end' (Habib 2013, 105). Not surprisingly, the NDP has been well received by industrial, financial, and agrarian elites.

\section{Poverty, inequality, and unemployment in post-apartheid South Africa}

South Africa is widely acknowledged as one of the world's most unequal countries in terms of land and income distribution. In fact, inequality increased in the post-apartheid period. Leibbrandt et al. demonstrate that the Gini coefficient had worsened from 0.66 in 1993 to 0.70 in 2008 (2010, 10). According to the EDD, the richest $10 \%$ of households earned $40 \%$ of national income. Moreover, while the portion of wages in national income declined from 50\% in 1994 to almost $45 \%$ in 2009, the share of profits grew from $40 \%$ to $45 \%$ (EDD 2010). These statistics are characterised by deep racial cleavages, with Africans overwhelmingly located in the poorest $70 \%$ and whites in the richest $10 \%$. In addition, poverty is widespread, with almost $50 \%$ of the population living below the poverty line of $\$ 2$ a day or R524 per month per person (NPC 2011). Since 1994, the pace of rural to urban migration has increased, and this urbanisation process has resulted in a shift in the 'poverty spread' between urban and rural areas. However, notwithstanding this shift, the 'depth of poverty remains deepest in rural areas' (Goldman and Reynolds 2008, 132; O'Laughlin et al. 2013).

Unemployment is a major problem confronting South Africa. According to StatsSA's Quarterly Labour Force Survey, the official unemployment rate rose from $24.9 \%$ in the last quarter of 2012 to $25.6 \%$ in the second quarter of 2013 while the expanded rate of unemployment (for those who have stopped looking for employment) rose to $36.8 \%$ (Berkowitz 2013). Disaggregating by race we find that the African and 'Coloured' communities suffer deeper levels of unemployment compared to Whites and Indians. Moreover, unemployment is quite high in rural areas. According to Dr Tsakani Ngomane, Deputy Director-General of the Department of Planning, Monitoring and Evaluation, located in the office of the President, government efforts at generating employment via the Comprehensive Rural Development Programme, the Expanded Public Works Programme, and Community Works Programme had minimal impact on rural unemployment. In fact, unemployment in 'tribal areas' rose from $44 \%$ in 2009 to $52 \%$ in 2012, partly due to the slow 
rate of national economic growth, inadequate progress with smallholders, and a lack of growth of employment uptake in the commercial agricultural sector (Ngomane 2012).

The post-apartheid government has made significant advances in providing water, electricity, and housing (Hemson, Carter, and Karuri-Sebina 2009). However, the extremely high rate of unemployment has adversely impacted the ability of poor households to access to crucial services such as water and electricity, especially in a context where GEAR policies enforce cost-recovery. The inability to pay for services and/or the lack of access to basic services has generated what Alexander (2010) calls a 'rebellion of the poor'. These 'service delivery protests' have spread across small rural towns and metropolitan areas (Alexander 2010; Mottiar and Bond 2012). In addition, the government has increased the number of social grants it has disbursed from 2.4 million in 1998 to 16 million in 2011, thus reaching almost 30\% of the population (Bhorat and Cassim 2014). Social grants have had a significant impact on reducing poverty and inequality. While media reporting on social grants is often negative, research shows that if grants to the poor were not expanded at this rate, then income inequality as measured by the Gini coefficient would have been considerably higher at 0.74 instead of 0.69 ' (Bhorat and Cassim 2014).

The socio-economic data provide a strong rationale for constructing a developmental state that will actively address deeply entrenched levels of poverty, inequality, and unemployment in both urban and rural South Africa. In the next section, we briefly evaluate land reform and rural development in South Africa.

\section{The state, land reform, and rural development in South Africa}

The developmental state has a central role to play in leading and sustaining rural development. This includes leading the process of land reform, promoting sustainable change in social and economic relations and supporting the goals of growth and development in the rural economy. (ANC 2008, 29)

The ANC is adamant that a 'developmental state' has to exercise a 'leading' or active role in promoting land reform and rural development. However, we first need to provide a very brief overview of the history of rural social relations in South Africa before appraising how the ANC government has promoted land reform and rural development as part of a larger national development strategy. Under colonialism and apartheid, millions of black South Africans were forced off the land. This land dispossession was officially codified in the Natives Land Act of 1913 and the Native Trust and Land Act of 1936, whereby the African majority was confined to $13 \%$ of the land in the former homelands. This state-driven process of 'accumulation by dispossession' (Harvey 2003) continued late into the twentieth century as the apartheid state forcibly evicted almost 3.5 million people from so-called Black Spots in rural 'white' South Africa between 1960 and 1980 (Platzky and Walker 1985). The colonial and apartheid legacy of violent land dispossession continues to shape South Africa's countryside in the post-apartheid era. Today South Africa is one of the most unequal countries in terms of land and income distribution, and almost $70 \%$ of the rural population lives below the poverty line (Hall 2004, 214; O'Laughlin et al. 2013). By the end of apartheid, $86 \%$ of all agricultural land was controlled by 60,000 white farmers while more than 13 million black people still live in the overcrowded 
former homelands that are characterised by low levels of economic development and extremely high levels of poverty compared to the rest of the country (Lahiff 2007, 1578).

The South African experience of accumulation by dispossession stands in stark contrast to the East Asian developmental states, where state-led redistributive land and agricultural reforms resulted in the emergence of a strong class of small-scale farmers (Evans 2010; Moyo 2010). To address high levels of land and income inequality as well as rural poverty, the ANC, through the Reconstruction and Development Programme (RDP), committed itself to redress this historic processes of land dispossession through land reform, restructure the dominant white commercial agricultural sector, develop a strong black small farmer sector, and build the economy by generating large-scale employment, increasing rural incomes and eliminating overcrowding [in the former homelands]' (ANC 1994, 20). On taking power in 1994, the ANC took on the RDP agenda and set itself a target of redistributing 30\% of white owned agricultural land to poor and landless black South Africans within 5 years. The state would provide redress through a three-pronged land reform programme that would: (a) restore land via the land restitution programme to those who were dispossessed under apartheid, (b) provide security of tenure to those living in the former homelands through the land tenure programme, and (c) redistribute land through the land redistribution programme to transform the racially skewed land holding pattern in South Africa (DLA 1997).

The ANC's land and agricultural policy was strongly influenced by the World Bank and committed the post-apartheid government to a market-led land reform programme that was based on a 'willing buyer, willing seller' principle (Williams 1996; Ntsebeza 2007, 126). In 1996, this rightward shift in economic policy was consolidated when the ANC officially adopted the neoliberal-inspired GEAR programme whilst maintaining the redistributionist rhetoric of the RDP. In line with GEAR, the 1997 White Paper on South African Land Policy officially embraced the willing buyer, willing seller principle (DLA 1997).

Between 1994 and 1999, land policies primarily focused on the landless and the rural poor which enabled them to access a Settlement and Land Acquisition Grant (SLAG) of R15,000 (later increased to R16,000). With the SLAG in hand, the Black rural poor (or willing buyers) were to identify a farm that they would purchase at market rates from white farmers (or willing sellers). Since R16,000 was too little to purchase a farm, 'willing buyers' had to pool their grants with other 'willing buyers' to acquire land, leading to what analysts call a 'rent-a-crowd' practice. The ANC-led state moved from an interventionist policy position of nationalising and redistributing land to the poor as ascribed in the Freedom Charter to a 'passive' state that refuses to intervene in the land market. In other words, rather than actively intervening in the market and expropriating land in the public interest, the ANC-led state has become what Pillay (2007) calls a 'facilitative' state that mediates transactions between willing buyers and willing sellers. However, the term 'willing buyer' is a misnomer in that there is nothing enthusiastic or willing about this buyer. Rather, state policy forces the rural poor to act as willing buyers in a market environment that is extremely unfavourable to them. 
Once on the land, beneficiaries struggled to make a living due to limited post-settlement support. Furthermore, the R16,00o SLAG was too little to purchase land, construct housing, and secure agricultural inputs to build livelihoods, resulting in many land reform beneficiaries underutilising land (Hall 2007; Aliber and Cousins 2013). In 1999, a government review concluded that the 'pro-poor' SLAG model was not reducing poverty nor creating jobs. So, it established the Land Redistribution for Agricultural Development (LRAD) programme, which was geared towards promoting a class of 'viable' black commercial farmers that would create jobs. LRAD provide larger grants ranging from R20,000 to R100,000 and, depending on own contributions, the grant could rise up to a maximum of R400,000 per individual (Aliber and Mokoena 2005). While redistribution of land increased under LRAD, job creation and poverty alleviation have been modest. For example, in an analysis of LRAD land reform projects in the Vhembe and Capricorn Districts of Limpopo province, Aliber and Cousins $(2013,158)$ found that:

from a Livelihoods perspective ... LRAD projects contributed little to poverty reduction, which the very modest labour intensification observed on some projects did very little to compensate. LRAD conspicuously failed to incorporate the poor and vulnerable as its main beneficiaries.

In large measure, government commitment to a speedy redistribution of land was undermined by the adoption of the willing buyer, willing seller policy. By 1999, less than $1 \%$ of agricultural land has been transferred, leading the government to push back the target date of redistributing $30 \%$ of land by 1999 to 2015. However, by February 2005, only 4\% of agricultural land had been redistributed, and by 2011 only $7.2 \%$. Given the slow pace of land delivery, the government once again moved the date for achieving the 30\% target to 2025 (Hall 2007, 88-89; O'Laughlin et al. 2013).

In recent years, there have some interesting developments in the land sector: the ANC's policy on land has become more pro-active while Agri SA, representing the commercial agricultural sector, has also come up with proposals that speaks to the NDP vision on rural development. This seems to have pleased the Minister of the Department Land Reform and Rural Development (DLRRD). The government is busy with legislation that will restrict the amount of agricultural land that can be purchased to 12,000 hectares, and has put forth policy proposals on 'Strengthening the Relative Rights of People Working the Land'. In terms of this proposal, the ownership of $50 \%$ of all commercial farms will be allocated to farm workers who will get shares based on the number of years they worked on the farm. Farmers will retain $50 \%$ of the farm, while the $50 \%$ that will be transferred to workers will paid by government and transferred into an Investment and Development Fund that will be jointly managed by all shareholders (DLRRD 2015; Erasmus 2014a). The 50/50 proposal has been strongly opposed by Agri SA and its affiliates, who argue that it is unconstitutional in that it undermines property rights and the market system. More importantly, they argue that these proposals contradict the NDP vision on land reform. Senior figures in the ANC have sought to downplay the proposal: Agriculture Minister, Senzeni Zokwana, said that the 50/50 plan was 'just a proposal' and that the 'ANC had not moved away from its policy of expropriation with compensation' (Erasmus 2014b). 
In response to the 50/50 proposal, Agri SA hosted a conference in October 2014, where it outlined its own land reform proposals, which were well received by the Minister of the DLRRD, Gugile Nkwinti. Johannes Moller, Agri SA President, stated that commercial farmers supported land reform and that District Committees, as outlined in the NDP, should identify land for redistribution, and provide training and technical support to potential beneficiaries. Moreover, a 'Special Purpose Vehicle' should be established to look into different land reform models and implement viable options. However, the land reform programme must be based on Chapter 6 of the NDP and that it must 'comply with the guidelines of the Constitution of South Africa; give full recognition to economic and market realities; not necessarily be dependent on state support; while utilising the potential of public- private partnerships as far as possible' (Möller 2014, 2). We will critically reflect on these proposals in the next section.

\section{From the RDP to the NDP: what future for land reform and rural development under a 'capable and developmental state'?}

In spite of the problems noted above, the South African Government views agriculture and land reform as having key roles to play in alleviating poverty and tackling high levels of unemployment. The NDP states that 'agriculture has the potential to create close to 1 million new [rural] jobs by 2030' and that 'Land reform' has a critical role to play in unlocking the 'potential for a dynamic, growing and employment-creating agricultural sector' (EDD 2010; NPC 2011, 219 and 226). The experience of land reform and rural development to date, however, suggests that this target is unlikely to be realised. In this section, we investigate why the land reform programme has failed to effectively tackle poverty, unemployment, and inequality. More specifically, we will focus on the politics of the government's land reform policy, the NDP's position on land reform and rural development, assess how a weak bureaucracy undermines government's developmental goals, and argue that the construction of a strong planning unit is critical in coordinating government action and promoting greater synergy between different government departments.

\section{The politics of the developmental state}

Politics play a crucial role in determining development success and failure. Indeed, as Left-wich (2005, 574-75) argues, the 'explicit promotion of development ... needs to be understood essentially and explicitly as a political process'. A developmental state, as conceptualised by the classical developmental state theorists, is autonomous and interventionist; it drives the developmental project in contradistinction to the minimalist neo-liberal state which leaves 'development ... in the hands of market forces' (Pillay 2007, 205). The adoption of the marketoriented willing buyer, willing seller land redistribution policy undermines this autonomous intervention, thus leaving the rural poor to the vagaries of the market. Poor 'willing buyers' have been poorly resourced in terms of infrastructure and financial resources that will enable them to make a living on the land. While the liberalisation of the agricultural sector commenced under the apartheid regime, the ANC's GEAR macro-economic policy deepened the neoliberal prescriptions of liberalising and deregulating the agricultural sector. The promulgation of the Marketing and Agricultural Products Act in 1996 resulted in the dismantling of agricultural marketing boards and the withdrawal of the state's role in the agriculture sector. Moreover, subsidies as well as tariffs on agricultural imports were removed, and state services to the 
agricultural sector were either withdrawn or reduced (Weideman 2004; Machethe 2008; Satgar 2011; O'Laughlin et al. 2013, 9) - all of which have left the South African agricultural sector with one of the lowest levels of state protection in the world (James 2007). These radical policy changes have adversely impacted new land reform beneficiaries who are denied the generous subsidies, infrastructure, marketing, and agricultural extension support provided to white farmers under apartheid (Lahiff and Cousins 2005).

The post-apartheid state's rationale in applying neoliberal shock-therapy in the white owned agricultural sector was to make it more competitive to better face the "winds of global competition ... loosen monopoly ownership and [thereby] create the conditions for deracializing the agro-food complex' (Satgar 2011, 180). In other words, competition would weed out weaker white commercial farmers who would be forced to sell, thus releasing land at cheaper prices for purposes of land redistribution and restitution. However, in practice, these market reforms produced a more concentrated large-scale commercial farming sector that became more capital intensive and actually shed jobs. Marginal white farmers were indeed forced off the land, but land did not necessarily end up in black hands. Rather, much of the land was transformed into private game farms, nature reserves or was bought by large white commercial farmers. As intended, these neoliberal reforms produced a smaller, leaner, and more competitive - but also a more capital intensive capitalist - agribusiness farming class that has become firmly integrated into the global economy. In addition, these neoliberal reforms forced large farmers to:

[B]ecome hard-nosed, unsentimental and commercially minded. ... For farmers bent on economic survival, mechanisation and the use of agricultural chemicals such as pesticides and herbicides became preferable to creating employment, especially in the context of labour and tenure legislation. (Atkinson 2007, 77)

These agricultural reforms, along with land tenure legislation which were meant to protect farmworkers from eviction, resulted in the expulsion of 2.4 million people between 1994 and 2004, with 'just under half of them actually evicted, the rest because conditions on the farms deteriorated so much' (Atkinson 2007, 85; Bundy 2013, 27). The high levels of farm evictions and the slow pace of land redistribution have led to a growing questioning within the ANC of government's steadfast adherence to the willing buyer, willing seller policy in general and of neoliberal economic policy in particular. For example, at the Polokwane Conference in 2007, the ANC passed a resolution questioning the efficacy of the willing buyer, willing seller policy (ANC 2008), and senior ANC member, Turok (2008, 11, original emphasis), argued that 'our society needs a transformational approach rather than a laissez-faire one'. Turok suggests that a developmental state rooted in a laissez faire economic trajectory will not speed up land reform and as a consequence will inhibit the creation of a million rural jobs. Developmental state policy based exclusively on the market is not designed to meet the pressing needs of South Africa's rural poor. Indeed, Edigheji $(2010,27)$ states that 'South Africa is unlikely to become a developmental state without agrarian reform occupying a prime place in its policy arsenal.' 
While the 50/50 proposal suggests a more interventionist stance, it was, however, not well received in the ANC. In fact, at the Agri SA conference, Minister Nkwinti related that:

When we published the 50/50 proposal, the very first call I got ... was from the SecretaryGeneral of the ANC, Gwede Mantashe. He said that 'I have bought myself a farm for R2 million and now you want to nationalise R1 million.' ... on TV I also saw the Treasurer- General of the ANC saying that the resolutions of the ANC do not speak to this thing [the 50/50 model].

It would appear that the proposal was more about putting pressure on the commercial agricultural sector to get to the land reform table rather than a radical departure from current policy. Reflecting on the 50/50 proposal, farmworkers, activists, and academics noted that 'there is nothing "ground-breaking" about this policy proposal, as it perpetuates the share equity model which has been so problematic for farm workers' (PLAAS 2014). Additionally, while Agri SA's proposals bring it closer to government, it does not significantly diverge from government policy as both are rooted in the willing buyer, willing seller framework. The problem with this rapprochement is that it does not deal with a fundamental question, namely, restructuring South Africa's unequal agrarian landscape. Moreover, the government's emphasis on creating a class of black capitalist farmers via LRAD - a position supported byAgri SA - suggests that the landless agrarian poor will remain marginalised.

A likely scenario is an alliance between the South African state and Agri SA to promote land reform. However, while the twentieth-century developmental state was ensconced within a tight developmental state-elite business nexus, the 21st developmental state will have to engage in a form of 'expanded embeddedness' through which civil society actors are also included as active participants in development planning and implementation (Williams 2014). Isaac (2014) shows how the provincial government in Kerala, India brought public institutions closer to citizens to enable them to actively participate in development at the local level, thus expanding human capabilities. Thus, democratic deliberation, rather than the authoritarianism of the twentiethcentury developmental state, must be the hallmark of a twenty-first century developmental state. In fact, Chibber (2014, 47 and 51) argues that there is no theoretical or empirical ground for arguing that 'democracy is an obstacle to a developmental state'. Rather, 'democracy might be a rather propitious setting for a developmental state' $(2014,51)$. In a similar vein, Kerstenetzky (2014) writes how the democratic Brazilian 'social developmental state' under the Lula administration (2003-2010) promoted 'redistributive growth' which raised the incomes of the poorest sectors at a higher rate than the richest quintile; provided above inflation increases in the minimum wage, thus increasing the purchasing power of the poor; implemented anti-cyclical economic policies which brought the unemployment rate to less than $7 \%$; and expanded conditional cash transfers (the Bolsa Familia) to almost 12 million families or $25 \%$ of the population. The Bolsa familia, which was conditional on children attending school and receiving vaccinations, has played an important role in reducing income inequality and extreme poverty.

While the Lula government made importance advances in tackling Brazil's problem of poverty and inequality, there was not as much progress in redistributing land, largely due to strong ties with agribusiness elites. This 'narrow embeddedness' between the state and agribusiness leads to 
elite capture of state resources to the detriment of small farmers and the landless. However, strong civil society organisations can also exert strong grassroots pressure to force the state to open up or expand embeddedness from below. For example, the Brazilian Landless Movement (MST) has used its direct action tactic of occupying land to pressure successive governments to redistribute more than seven million hectares of agricultural land on which one and half million members farm (Karriem 2009, 2013). Moreover, research has shown that MST mobilisations have improved the livelihoods of land reform settlers, with many experiencing improvements in life expectancies, incomes, and educational standards (Medeiros and Leite 2004; Carter 2010).

In South Africa, civil society in urban areas has exercised an insurgent role in pressuring government to provide services as witnessed by rising service delivery protests (Alexander 2010). The slow pace of land reform is also due to weak rural social movements, and the decline of the Landless People's Movement has meant that government has not felt compelled to implement a more radical rural development programme. The building of a strong grassroots movement/s as in Brazil - is thus crucial if South Africa's rural poor are to gain access to land and capabilityenhancing services. It is through using their collective agency to expand embeddedness from below that the rural poor will be able to challenge the many constraints that undermine their entitlements to land and other capability-enhancing services. Moreover, it is through insurgent mobilisations from below that the state can be held accountable to provide much needed services to enable small farmers to improve their livelihoods. A thorough-going process of land and agrarian reform programme in which the rural poor plays an active part can set in motion a process that tackles high levels of poverty and inequality and creates a class of small farmers to spur rural development.

\section{The developmental state and an effective bureaucracy}

The establishment of an efficient and disciplined bureaucracy is recognised as a key feature of successful developmental states. Moreover, successful developmental states maintain their autonomy from predatory elites through establishing Weberian meritocratic bureaucracies that are committed to advancing national development goals (Amsden 1989; Evans 2010). While the South African state displays Weberian meritocratic characteristics (like in the South African Revenue Service, the Treasury, and Ministry of Finance, where highly skilled and highly paid personnel are employed), there is widespread recognition, including by government, that the bureaucracy is inefficient, lacks skilled personnel, has poor management, is beset by cadre deployment, and is dysfunctional in many provinces and municipalities - all of which undermine the realisation of developmental goals (Von Holt 2010; Chipkin 2013). In this regard, Terreblanche $(2009,117)$ notes that instead of displaying a culture of service, the public service has become renowned for careerism, nepotism and even corruption, while many of its senior officials are guilty of doubtful moral behaviour'. The growing number of corruption cases in which senior government officials are involved in brings to mind Evans' (1995) distinction between developmental, predatory, and intermediate states. Following Evans, South Africa would be classified as an intermediate state as it exhibits both predatory and developmental features: sectors of the state bureaucracy are captured by predatory elites who feed their personal interests, but the 
bureaucracy also contains pockets of Weberian excellence and efficiency that are committed to a developmental project.

Baissac (2009) attributes the weakness of the government's administrative capacity to the 1994 regime change and overhaul of the public service which resulted in the loss of considerable knowledge as experienced white bureaucrats were replaced by often inexperienced black bureaucrats. This 'changing of the guard' occurred extremely rapidly, and without adequate knowledge management or skills transfer to maintain and improve service levels (Baissac 2009, 12; Terreblanche 2009). In addition, Von Holt (2010), a national planning commissioner, explains how affirmative action and the skills shortage created numerous opportunities for upward mobility in the bureaucracy, generating a powerful culture of moving onward and upward. The culture of upward mobility encourages an attitude of 'facing upward' towards the next job prospect rather than focusing downward on improving the effective functioning of the state. Consequently, there has been high staff turn-over as public servants move from one post to the next, which makes it difficult to create a stable environment and nurture skill sets for specific jobs. This orientation towards upward mobility and careerism undermines work performance and the construction of a stable, functioning bureaucracy (Von Holt 2010, 11). A key consequence of weak administrative competence has been the outsourcing of government functions to consultants at great cost to the fiscus (Chipkin 2013; Kraak 2011). For example, poor capacity in the then Department of Land Affairs resulted in legions of consultants [being invited] to assist' land reform beneficiaries 'prepare their business plans'. In many instances, the consultants simply appeased the 'fears of government officials (and thus getting their projects approved with relative ease) by offering rosy cash-flow projections that commonly even the consultants did not believe' (Aliber and Mokoena 2005, 334). This example highlights the need for building an effective bureaucracy if the NDP's developmental goals of redistributing 30\% white owned agricultural land to black farmers by 2025 and creating a million rural jobs by 2030 are to be realised.

\section{A central planning agency: the NPC?}

Most successful development states had strong central planning agencies with cross-cutting powers to intervene in government departments and ensure that long-term development plans are implemented. For example, Japan's Ministry of International Trade and Industry, Korea's Economic Planning Board, and Malaysia's Economic Planning Unit took active roles in driving and coordinating NDPs. These central planning agencies were located in the office of the head of state and were staffed by highly skilled and competent bureaucrats who had the capacity to intervene in government departments and ensure that policies were implemented.

South Africa's NDP and numerous government documents point to weak inter-governmental coordination as one of the principal challenges to be addressed by the state (Kraak 2011; NPC 2011). This concern is a long-standing one, as the late Peter Mokaba, a former deputy minister of Environmental Affairs, noted in 2001: 'coordination of planning, budgeting and personnel still eludes us' (quoted in Gumede 2009, 10). While correctly diagnosing the problem of weak coordination, the NDP provides few specifics as to what a central coordinating agency would look like or whether the NPC would be that agency. Currently, the NPC is constituted by 26 
part-time commissioners, the majority of whom are located in academia and the private sector. If South Africa is to ensure that its long-term developmental goals are met, it will have to build a strong planning agency that is rooted in the state and society. Moreover, if rural economies are to be revitalised through 'improved infrastructure and service delivery' and increased 'investments in irrigation infrastructure' (NPC 2011, 58), then a strong central planning agency will be crucial in cutting through interdepartmental inertia at the national level and ensuring that local, provincial, and national government agencies engage in coordinated action to deliver infrastructure and services. The failure of the RDP Ministry, headed by Jay Naidoo, was in large measure due to the weak power it had in coordinating implementation across national departments. The extent to which South Africa succeeds in establishing a 'capable developmental state' will depend on it building a centralised planning agency with a skilled and competent bureaucracy that has the power to coordinate and ensure that departments work together in realising development goals.

\section{Conclusion}

In this paper, we critically evaluated the performance of the post-apartheid South African state under the RDP and GEAR macro-economic frameworks, especially as it relates to the land reform and rural development programme. Furthermore, we assessed the future action of the NDP under the proposed capable developmental state. Our central argument is that the government's market-oriented 'willing buyer, willing seller' land policy and a weak bureaucracy are major barriers to meeting the target of redistributing $30 \%$ of white agricultural land to black farmers, creating jobs, and eradicating poverty. Moreover, we posited that the NDP is essentially a continuation of the GEAR macroeconomic framework in that it leaves the market-oriented focus of land and agricultural policy intact. As such, we contended that the NDP is unlikely to radically transform the agrarian sector or create a million new jobs in rural South Africa. We also argued that South Africa's development policies should not only focus on economic growth per se, but rather that it should also actively promote and extend capability-enhancing services such as education, literacy programmes, and health care, so that the rural population's human development is also expanded. Finally, we argued that the NDP's objectives will only be achieved through a developmental state that directs the 'market' rather than be led by it, and that incorporates civil society actors. Moreover, a developmental state will have to construct a skilled and competent bureaucracy, a centralised planning agency that has the power to coordinate and ensure that government departments work together and implement policies according to plan, and that will actively intervene in the economy to meet the country's developmental objectives.

\section{Acknowledgements}

We would like to thank the two reviewers for their extremely helpful comments which helped refine the central arguments of this paper. We would also like to thank Rashid Ahmed for commenting on an early version of this paper.

\section{Disclosure statement}

No potential conflict of interest was reported by the authors. 


\section{References}

Alexander, Peter. 2010. "Rebellion of the Poor: South Africa's Service Delivery Protests - A Preliminary Analysis." Review of African Political Economy 37 (123): 25-40.

Aliber, Michael, and Ben Cousins. 2013. "Livelihoods After Land Reform in South Africa." Journal of Agrarian Change 13 (1): 140-165.

Aliber, Michael, and Reuben Mokoena. 2005. "The Land Question in Contemporary South Africa." In State of the Nation: South Africa 2004-2005, edited by John Daniel, Adam Habib, and Roger Southall, 330-346. Cape Town: HSRC Press.

Amsden, Alice H. 1989. Asia's Next Giant. Oxford: Oxford University Press.

ANC. 1994. The Reconstruction and Development Programme: A Policy Framework. Johannesburg: Umanyano Publications.

ANC. 2008. "Extracts from 2007 [ANC] Conference Documents: Rural Development, Land Reform and Agrarian Change." In Wealth Doesn't Trickle Down: The Case for a Developmental State, edited by Ben Turok, 12-35. Cape Town: New Agenda.

Atkinson, Doreen. 2007. Going for Broke: The Fate of Farmworkers in Arid South Africa. Cape Town: HSRC Press.

Baissac, Claude. 2009. "A South African Developmental State? A Critical Perspective." Accessed August 31, 2013. http://issuu.com/claudebaissac/docs/.

Berkowitz, Paul. 2013. SA's Unemployment Rate Rise to Near-Record Levels. Daily Maverick, August 2. Bhorat, Haroon, and Aalia Cassim. 2014. "South Africa's Welfare Success Story II: PovertyReducing Social Grants." Accessed October 20, 2015. http://www.brookings.edu/blogs/africa-in-focus/posts/2014/01/27-south-africa-welfarepoverty-bhorat.

Bundy, Collin. 2013. "Centenary of the 1913 Land Act." Amandla! 30: 25-27.

Byres, Terence. 1996. Capitalism from Above and Capitalism from Below: An Essay in Comparative Political Economy. London: McMillan.

Carter, Miguel, ed. 2010. Combatendo a Desigualdade Social: O MST e a Reforma Agraria no Brasil. Sao Paulo: Editora UNESP.

Chibber, Vivek. 2014. "The Developmental State in Retrospect and Prospect: Lessons from India and South Korea." In The End of the Developmental State? edited by Michelle Williams, 30-54. Pietermaritzburg: UKZN Press.

Chipkin, Ivor. 2013. "Wither the State? Corruption, Institutions and State-building in South Africa." Politikon 40 (2): 211-231.

COSATU. 2005. "A Developmental State for South Africa?" Discussion Paper for the 2005 Central Committee Meeting, Johannesburg.

DLA (Department of Land Affairs). 1997. The White Paper on South African Land Policy. Pretoria: Government of South Africa.

DLRRD. 2015. "Strengthening Relative Rights of People Working the Land: Policy Proposals." Accessed October 20, 2015. http://www.ruraldevelopment.gov.za/publications/landreform- indaba-2015/file/3404-drdlr-policy-proposals.

EDD (Economic Development Department). 2010. The New Growth Path: The Framework. Pretoria: Economic Development Department.

Edigheji, Omano. 2010. "Introduction: Constructing a Democratic Developmental State in South Africa: Potentials and Challenges." In Constructing a Democratic Developmental State in 
South Africa: Potentials and Challenges, edited by Omano Edigheji, 1-33. Cape Town: HSRC Press.

Erasmus, Denene. 2014a. "Land Reform Proposal a Snub to the NDP." Accessed October 15, 2015. http://www.farmersweekly.co.za/article.aspx?id = 61543\&h = Land-reform-proposal-asnub-to- the-NDP.

Erasmus, Denene. 2014b. "No Expropriation Without Compensation - Zokwana." Accessed October 15, 2015. http://www.farmersweekly.co.za/news.aspx?id=61787\&h=Noexpropriation-without- compensation-\%E2\%80\%93-Zokwana.

Evans, Peter. 1995. Embedded Autonomy: States and Industrial Transformation. Princeton, NJ: Princeton University Press.

Evans, Peter. 2010. "Constructing the $21^{\text {st }}$ Century Developmental State: Potentialities and Pitfalls." In Constructing a Democratic Developmental State in South Africa: Potentials and Challenges, edited by Omano Edigheji, 37-58. Cape Town: HSRC Press.

Evans, Peter. 2014. "The Developmental State: Divergent Responses to Modern Economic Theory and the Twenty-First Century Economy." In The End of the Developmental State? edited by Michelle Williams, 220-240. Pietermaritzburg: UKZN Press.

Evans, Peter, and Dietrich Rueschemeyer. 1985. "The State and Economic Transformation: Toward an Analysis of the Conditions Underlying Effective Intervention." In Bringing the State Back, edited by Peter Evans, Dietrich Rueschemeyer, and Theda Skocpol, 44-77. Cambridge: Cambridge University Press.

Goldman, Ian, and Kian Reynolds. 2008. "Rural Local Governance." In Consolidating Developmental Local Government: Lessons from the South African Experience, edited by Mirjam von Donk, Mark Swilling, Edgard Pieterse, and Susan Parnell, 131-152. Cape Town: UCT Press.

Gumede, Willam. 2009. Delivering the Democratic Developmental State in South Africa. Development Planning Division. Working Paper Series No. 9. Midrand: DBSA.

Habib, Adam. 2013. South Africa's Suspended Revolution: Hopes and Prospects. Johannesburg: Wits University Press.

Hall, Ruth. 2004. "A Political Economy of Land Reform in South Africa." Review of African Political Economy 31 (100): 213-227.

Hall, Ruth. 2007. "Transforming Rural South Africa? Taking Stock of Land Reform.” In The Land Question in South Africa: The Challenge of Transformation and Redistribution, edited by Lungisile Ntsebeza and Ruth Hall, 87-106. Cape Town: HSRC Press.

Harvey, David. 2003. The New Imperialism. New York: Oxford University Press.

Hemson, David, Jonathan Carter, and Geci Karuri-Sebina. 2009. "Service Delivery as a Measure of Change: State Capacity and Development." In State of the Nation: South Africa 2008, edited by Peter Kagwanja and Kwandiwe Kondlo, 151-177. Cape Town: HSRC Press.

Isaac, Thomas. 2014. "Politics of Democratic Decentralization and the Developmental State: A Study of the Kerala Experience." In The End of the Developmental State? edited by Michelle Williams, 197-219. Pietermaritzburg: UKZN Press.

James, Deborah. 2007. Gaining ground? 'Rights' and 'Property' in South African Land Reform. London: Routledge.

Johnson, Chalmers. 1982. MITI and the Japanese Miracle: The Growth of Japanese Industrial Policy, 1925-1975. Stanford, CA: Stanford University Press. 
Johnson, Chalmers. 1986. "The Non-socialist NICs: Comments." International Organization 40 (2): 547-575.

Karriem, Abdurazack. 2009. "The Rise and Transformation of the Brazilian Landless Movement into a Counter-hegemonic Political Actor: A Gramscian Analysis." Geoforum 40 (3): 316325 .

Karriem, Abdulrazak. 2013. "Space, Ecology, and Politics in the Praxis of Brazil's Landless Movement." In Gramsci: Space, Nature, Politics, edited by Michael Ekers, Gillian Hart, Stefan Kipfer, and Alex Loftus, 142-160. London: Wiley-Blackwell.

Kerstenetzky, Celia Lessa. 2014. "The Brazilian Social Development State: A Progressive Agenda on a (Still) Conservative Political Society.” In The End of the Developmental State? edited by Michelle Williams, 172-196. Pietermaritzburg: UKZN Press.

Kraak, Andre. 2011. "Horizontal Coordination, Government Performance and National Planning: The Possibilities and Limits of the South African State." Politikon 38 (3): 343-365.

Lahiff, Edward. 2007. "Willing Buyer, Willing Seller': South Africa's Failed Experiment in MarketLed Agrarian Reform.” Third World Quarterly 28 (8): 1577-1597.

Lahiff, Edward, and Ben Cousins. 2005. "Smallholder Agriculture and Land Reform in South Africa." IDS Bulletin 36 (2): 127-131.

Leftwich, Adrian. 2005. "Politics in Command: Development Studies and the Rediscovery of Social Science.” New Political Economy 10 (4): 573-607.

Leibbrandt, Murray, Ingrid Woolard, Arden Finn and Jonathan Argent. 2010. Trends in South African Income Distribution and Poverty since the fall of Apartheid. OECD Social, Employment and Migration Working Papers. No. 101, SALDRU. Cape Town: University of Cape Town.

Machethe, Charles. 2008. "Developmental State: Implications for Rural Development in South Africa." In Wealth Doesn't Trickle Down: The Case for a Developmental State in South Africa, edited by Ben Turok, 112-123. Cape Town: New Agenda.

Makgetla, Neva. 2008. "A Developmental State for South Africa?” In Wealth Doesn't Trickle Down: The Case for a Developmental State in South Africa, edited by Ben Turok, 140-158. Cape Town: New Agenda.

Medeiros, Leonilde Sèrvolo de, and Sèrgio Perreira Leite. 2004. Assentamentos Rurais: Mudanca Social e Dinamica Regional. Rio de Janeiro: Maud.

Mottiar, Shauna, and Patrick Bond. 2012. "The Politics of Discontent and Social Protest in Durban." Politikon 39 (3): 309-330.

Moyo, Sam. 2010. "The Agrarian Question and the Developmental State in Southern Africa." In Constructing a Democratic Developmental State in South Africa: Potentials and Challenges, edited by Omano Ediheji, 285-314. Cape Town: HSRC Press.

Möller, Johannes. 2014. “Agri SA's Holistic Plan for Land Reform in South Africa.” Accessed October 1, 2015. http://www.agrisa.co.za/wp-content/uploads/2014/11/eng_Holistiese-plan-virgrondhervorming- Eng-FIN.pdf.

Ngomane, Tsakani. 2012. "Rural Development \& Land Reform Department: DPME Management Performance Assessment \& Audit Outcomes." Accessed February 9, 2015. https://pmg.org.za/ committee-meeting/14933/.

NPC (National Planning Commission). 2011. National Development Plan: Vision 2030. Pretoria: National Planning Commission. 
Ntsebeza, Lungisile. 2007. "Land Redistribution in South Africa: The Property Clause Revisited." In The Land Question in South Africa: The Challenge of Transformation and Redistribution, edited by Lungisile Ntsebeza and Ruth Hall,107-131. Cape Town: HSRC Press.

O'Laughlin, Bridget, Henry Bernstein, Ben Cousins, and Pauline E. Peters. 2013. "Introduction: Agrarian Change, Rural Poverty and Land Reform in South Africa Since 1994." Journal of Agrarian Change 13 (1): 1-15.

Öniş, Ziya. 1991. "The Logic of the Developmental State." Comparative Politics 24 (1): 109-26.

Pillay, Devin. 2007. "The Stunted Growth of South Africa's Developmental State Discourse." Africanus 37 (2): 198-215.

PLAAS. 2014. A Critical Response to Government's Farm Worker Proposals: 'Strengthening the Relative Rights of People Working the Land'. Workshop Report. Bellville: University of the Western Cape. Platzky, Laurine, and Cherryl Walker. 1985. The Surplus People: Forced Removals in South Africa. Johannesburg: Raven.

Satgar, Vishwas. 2011. "Challenging Globalized Agro-food Complex: Farming Cooperatives and the Emerging Solidarity Economy.” WorkingUSA: The Journal of Labor and Society 14: 177-190.

Terreblanche, Sampie. 2009. "The Developmental State in South Africa: The Difficult Road Ahead." In State of the Nation: South Africa 2008, edited by Peter Kagwanja and Kandiwe Kondlo, 107130. Cape Town: HSRC Press.

Turok, Ben. 2008. "Seminar Report: Is the Developmental State really Controversial?” In Wealth Doesn't Trickle Down: The Case for a Developmental State, edited by Ben Turok, 3-11. Cape Town: New Agenda.

Von Holt, Karl. 2010. "Nationalism, Bureaucracy and the Developmental State: The South African Case." South African Review of Sociology 41 (1): 4-27.

Wade, Robert. 1990. Governing the Market: Economic Theory and the Role of Government in East Asian Industrialisation. Princeton, NJ: Princeton University Press.

Weideman, Marida. 2004. "Who Shaped South Africa's Land Reform Policy?” Politikon 31 (2): 219238. Williams, Gavin. 1996. "Setting the Agenda: A Critique of the World Bank's Rural Restructuring Programme for South Africa." Journal of Southern African Studies 22 (1): 139166.

Williams, Michelle. 2014. "Rethinking the Developmental State in the Twenty-first Century." In The End of the Developmental State? edited by Michelle Williams, 1-29. Pietermaritzburg: UKZN Press. 